\title{
Nutritional and antibacterial treatments of live food organisms : the influence on survival, growth rate and weaning success of Turbot (Scophthalmus maximus)
}

\author{
François-Joël GATESOUPE \\ I.N.R.A., Laboratoire d'Elevage et de Nutrition des Poissons \\ Centre de Recherches hydrobiologiques \\ Saint-Pée-sur-Nivelle, F 64310 Ascain
}

\begin{abstract}
Summary
After ingestion of nutrients and/or antibacterial drug, live food organisms were given to turbot (Scophthalmus maximus) larvae. When the rotifer Brachionus plicatilis was treated with the drug, between 21 and 33 p. 100 of the larvae survived to day 14, whereas survival was quite poor without this treatment. When rotifers were also enriched with nutrients, survival rate of turbot on day 14 was between 36 and $69 \mathrm{p}$. 100. It was concluded that a pathological infection was probably encountered during these experiments, while the dietary value of rotifers would also be implicated in the early survival of turbot. Nauplii, then metanauplii of Artemia salina were supplied afterwards with the same treatments. The weaning onto a compound diet started on day 30 , and by day 45 the survival of turbot which had been fed with enriched live organisms was between 17 and 35 p. 100 with a mean weight between 225 and $630 \mathrm{mg}$. When the live food organisms had not been enriched, survival on day 45 was between 5 and 14 p. 100 , and the mean weight was between 130 and $170 \mathrm{mg}$. Though, the growth rates with or without enrichment were not clearly different before weaning, the enrichment of live food organisms appears therefore to be helpful in preparing turbot to be weaned while keeping an excellent growth rate. The value of treating Artemia with the antibacterial drug was not determined in this preliminary study.
\end{abstract}

\section{Introduction}

It was reported by Jones, Prickett \& Douglas (1981), that turbot (Scophthalmus maximus) larvae were frequently affected by a high mortality during their first days of feeding. This mortality might originate from nutritional or pathological causes. SCOTT \& MidDLETON (1979) pointed out, on the one hand, that good survival might be ensured by a daily supply of algae into the tanks in which turbot were fed on the rotifer Brachionus plicatilis, provided that these algae were not deficient in long-chain polyunsaturated fatty acids. BUCKE (1980), on the other hand, investigated the pathological histology of turbot larvae - which were dying in large numbers - and diagnosed a bacterial infection in one of the three related cases. 
The use of compound diets for rotifer feeding (GATEsoupe \& RoBIN, 1981) and the enrichment of these live food organisms just before being offered to fish larvae (GATESOupe \& LuQueT, 1981) were therefore possible ways of improving the early survival rate of turbot. The purpose of doing this was in connection with the suggestion of Fontaine \& Revera (1980), who considered the rotifer as a carrier medium for nutrients. In order to prevent turbot from a possible infection, the rotifers could be also used for carrying an antibacterial drug.

In practice, rotifers fed with the alga Platymonas (= Tetraselmis) suecica, or with a compound diet, were given to larvae. A third variation of dietary value was obtained by enriching with nutrients rotifers which had been fed on compound diet. Some of these rotifers - enriched or not - were treated with an antibacterial agent just before being offered to larvae. The effects on growth and survival rates of turbot were compared at the end of this first step of the food sequence.

Because the survival of turbot is precarious throughout the live food and weaning stages, Artemia were treated in the same way as the rotifers and the experiments were continued until the fish had established feeding on a prepared diet. Indeed, Howeli, Bromley \& Adkins (1981) examined the dietary value of Artemia nauplii for turbot, and found that the fish growth and survival rates were different when they had been fed on two strains of Artemia, with a marked effect on their compounddiet acceptance. These authors reduced these differences by prefeeding the deficient strain of Artemia on algae, on condition that these algae were also supplied into the larval rearing tanks.

\section{Material and methods}

\section{A. General design}

Three experiments were carried out on 3 or 4 lots, according to the design reported in table 1 . The three variations of dietary value were tested on the rotifers in experiment 1. Then treatment $A$ (algae-fed rotifers) was withdrawn from experiments 2 and 3, where all the rotifers - enriched (treatment DE) or not (treatment D) - were fed on a compound diet. The effect of treating rotifers with an antimicrobial agent (treatments DT and DET) was examined in experiments 1 and 2 . This treatment was extended to all the lots of experiment 3 , where the possibility of a complementary effect between enrichment and treatment was further investigated.

Artemia were enriched and/or treated in the same way as the rotifers. The value of doing this could not be examined separately, because there was no possibility of duplicating the lots.

Initial conditions of the newly-hatched turbot are reported in table 2. They were put into 2501 cylindrical tanks with hemispheric bottoms, in an open system maintained at $20 \pm 1$ " $\mathrm{C}$ water temperature (fig. 1). The rearing technique was described by GIRIN (1979). 
TABLE 1

Reference code of the experimental groups.

Code des références des lots expérimentaux.

\begin{tabular}{|c|c|c|c|}
\hline Experiment & 1 & 2 & 3 \\
\hline $\begin{array}{l}\text { Tribrissen treatment }(\mathrm{T}) \text { : } \\
- \text { compound diet-fed rotifers (DT) } \ldots \ldots \ldots \ldots \\
\text { - enrichment of the compound diet-fed rotifers } \\
\quad \text { (DET) } \ldots \ldots \ldots \ldots \ldots \ldots \ldots \ldots \ldots \ldots \ldots\end{array}$ & $1 \mathrm{DET}$ & $\begin{array}{l}\text { 2' DT } \\
2 \text { DET }\end{array}$ & $\begin{array}{l}3 \text { DT } 1,3 \text { DT } 2 \\
3 \text { DET 1, } 3 \text { DET } 2\end{array}$ \\
\hline 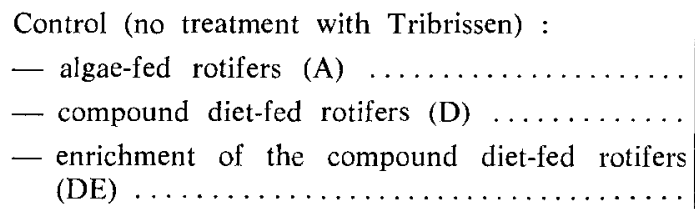 & $\begin{array}{l}1 \mathrm{~A} \\
1 \mathrm{D} \\
1 \mathrm{DE}\end{array}$ & $\frac{-}{2 \mathrm{D}}$ & - \\
\hline
\end{tabular}

TABle 2

Initial conditions and food sequence of each experiment.

Conditions expérimentales initiales et séquences alimentaires utilisées.

\begin{tabular}{|c|c|c|c|c|c|c|}
\hline Experiment & \multicolumn{2}{|c|}{1} & \multicolumn{2}{|c|}{2} & \multicolumn{2}{|c|}{3} \\
\hline $\begin{array}{l}\text { Initial fish density } / 1 \ldots \ldots \ldots \ldots \ldots \\
\text { Initial mean weight }(\mathrm{mg}) \\
\text { Initial mean length }(\mathrm{mm}) \\
\text { Number of lots } \ldots \ldots \ldots \ldots \ldots\end{array}$ & \multicolumn{2}{|c|}{$\begin{array}{l}20 \\
0.15 \\
3.3 \\
4\end{array}$} & \multicolumn{2}{|c|}{$\begin{array}{l}17 \\
0.14 \\
2.4 \\
3\end{array}$} & \multicolumn{2}{|c|}{$\begin{array}{l}20 \\
0.18 \\
2.7 \\
4\end{array}$} \\
\hline $\begin{array}{c}\text { Food sequence (day numbered } \\
\text { from hatching) }\end{array}$ & $\begin{array}{l}\text { 1rst } \\
\text { day }\end{array}$ & $\begin{array}{l}\text { last } \\
\text { day }\end{array}$ & $\begin{array}{l}\text { 1rst } \\
\text { day }\end{array}$ & $\begin{array}{l}\text { Tast } \\
\text { day }\end{array}$ & $\begin{array}{l}1 \text { rst } \\
\text { day }\end{array}$ & $\begin{array}{l}\text { last } \\
\text { day }\end{array}$ \\
\hline Feeding on rotifers $\ldots \ldots \ldots \ldots \ldots$ & 3 & 14 & 3 & 15 & 3 & 14 \\
\hline $\begin{array}{l}\text { Feeding on Artemia : } \\
\text { — nauplii } \ldots \ldots \ldots \ldots \ldots \ldots \ldots \ldots \ldots\end{array}$ & $\begin{array}{r}9 \\
18\end{array}$ & $\begin{array}{l}23 \\
34\end{array}$ & $\begin{array}{r}9 \\
16\end{array}$ & $\begin{array}{l}19 \\
35\end{array}$ & $\begin{array}{r}9 \\
15\end{array}$ & $\begin{array}{l}20 \\
34\end{array}$ \\
\hline $\begin{array}{l}\text { Metanauplii enrichment }: \\
-5 \mathrm{~g} \text { per } 10^{6} \text { Artemia } \ldots \ldots \ldots \ldots \\
-2.5 \mathrm{~g} \text { per } 10^{6} \text { Artemia } \ldots \ldots \ldots \ldots\end{array}$ & $\begin{array}{l}18 \\
31\end{array}$ & $\begin{array}{l}30 \\
34\end{array}$ & $\begin{array}{l}16 \\
24\end{array}$ & $\begin{array}{l}23 \\
35\end{array}$ & $\begin{array}{l}15 \\
23\end{array}$ & $\begin{array}{l}22 \\
34\end{array}$ \\
\hline Feeding on compound diet ... & 31 & 45 & 31 & 45 & 31 & 45 \\
\hline
\end{tabular}




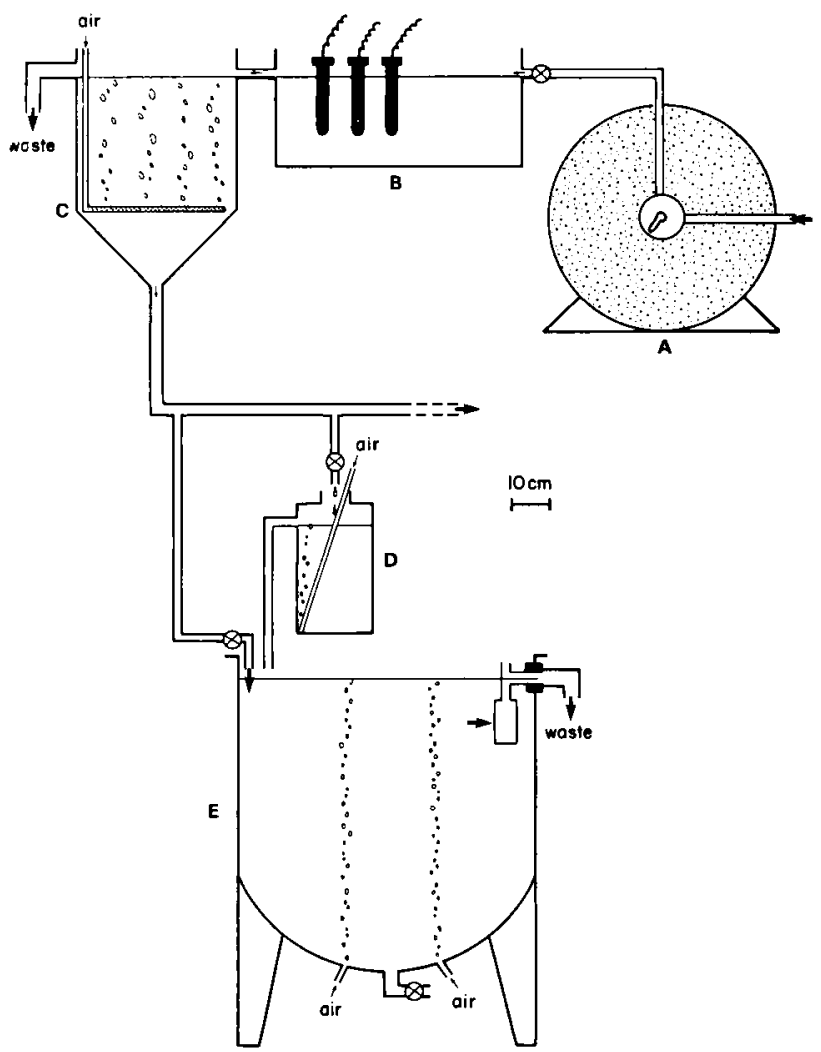

Frg. 1

Experimental rearing unit for turbot larvae.

Unité d'élevage larvaire des turbots.

A : Pressure filter with sand. B : Thermostated heating unit. C : Expansion tank for supersaturating gas. D : Live food supply. E : Larval rearing tank.

$A$ : Filtre à sable sous pression. $B$ : Système de réchauffement de l'eau avec thermostat. $C$ : Bac de détente pour les gaz en sursaturation. $D$ : Distribution des proies vivantes. $E:$ Bac d'élevage larvaire.

Twenty fish were sampled for growth analysis at days $0,10,15,20$ and 30 . The final mean weight and length were estimated at day 45 by sampling 50 fish. Weight and length data were compared between lots within each experiment and each date by the test of Kruskall and Wallis; when a difference was found significant, each lot was compared to each other by the simultaneous test procedure of Dwass. These tests were reported by SoKal \& RoHLF (1969).

The survivors were counted on days 30 and 45. Survival was estimated daily by counting the dead from day 15 . The larvae which died before this date were too small and decomposed too rapidly to allow an accurate estimate of survival. 


\section{B. Food, enrichment and treatment of live food organisms}

In the food sequences reported in table 2, three kinds of live organisms were used : rotifers-fed either on algae, Platymonas suecica, or on a compound diet (tabl. 3) - freshly-hatched Artemia nauplii, and Artemia metanauplii — obtained by feeding nauplii for 48 hours on another compound diet (tabl. 3).

\section{TABLE 3}

Composition of the mixed diets (in $g$ per $100 \mathrm{~g}$ dry weight).

Composition des aliments inertes utilisés (en g p. 100 de matière sèche).

\begin{tabular}{|c|c|c|c|c|}
\hline Raw material & Rotifer diet & Artemia diet & $\underset{\text { mix }}{\text { Enrichment }}$ & Turbot diet \\
\hline Spray-dried Spirulina $\ldots \ldots \ldots \ldots$ & 40 & 40 & - & - \\
\hline IFP yeast $\ldots \ldots \ldots \ldots \ldots \ldots \ldots$ & 40 & 40 & - & - \\
\hline Fish autolysate $\ldots \ldots \ldots \ldots \ldots \ldots$ & - & - & 73 & - \\
\hline Casein $\quad \ldots \ldots \ldots \ldots \ldots \ldots \ldots \ldots$ & - & - & - & 29.2 \\
\hline Cod meal $\ldots \ldots \ldots \ldots \ldots \ldots \ldots$ & - & - & - & 25.5 \\
\hline Clam flesh $\ldots \ldots \ldots \ldots \ldots \ldots$ & - & - & - & 8.1 \\
\hline Wheat gluten $\ldots \ldots \ldots \ldots \ldots \ldots$ & - & - & - & 9.9 \\
\hline DL-methionine $\ldots \ldots \ldots \ldots \ldots \ldots$ & - & 1 & 2 & 05 \\
\hline D-glucosamine hydrochloride & 0.5 & 0.5 & - & - \\
\hline Corn starch $\ldots \ldots \ldots \ldots \ldots \ldots$ & 9.9 & 7.9 & - & - \\
\hline Cod liver oil $\ldots \ldots \ldots \ldots \ldots \ldots$ & 4 & 4 & 10 & 5 \\
\hline Corn oil $\ldots \ldots \ldots \ldots \ldots \ldots \ldots$ & - & - & - & 10 \\
\hline Cholesterol $\ldots \ldots \ldots \ldots \ldots \ldots \ldots$ & - & 1 & - & - \\
\hline Vitamin premix (a) $\ldots \ldots \ldots \ldots \ldots$ & 3.2 & 3.2 & 9.6 & 6.3 \\
\hline Choline chloride $\ldots \ldots \ldots \ldots \ldots$ & 2 & 2 & 4 & 2 \\
\hline $\mathrm{Ca} \mathrm{HPO}, \ldots \ldots \ldots \ldots \ldots \ldots \ldots$ & 03 & 0.3 & 1 & 0.6 \\
\hline $\mathrm{Fe} \mathrm{SO}_{4}, 7 \mathrm{H}_{2} \mathrm{O} \ldots \ldots \ldots \ldots \ldots$ & 01 & 0.1 & 0.4 & 0.2 \\
\hline Carophyll red $\ldots \ldots \ldots \ldots \ldots \ldots$ & - & - & (b) & 0.5 \\
\hline Sodium alginate & - & - & - & 2.2 \\
\hline
\end{tabular}

(a) GATESOUPE \& LuQuet (1981).

(b) Added separately for enriching the rotifers.

The enrichment of rotifers was previously described (GATESOUPE \& LUQUET, 1981 ; Gatesoupe \& RoBin, 1982). We added to mixed powders and oil (tabl. 3), Carophyll red ${ }^{\circledR}$ (Canthaxanthin at 10 p. 100 from Hoffmann-La Roche) as a colouring agent. Indeed, the gut content of compound died-fed rotifers is pale, and canthaxanthin might improve their visibility to turbot larvae. The proportions used were $1.5 \mathrm{~g}$ enrichment mix and $0.5 \mathrm{~g}$ Carophyll per $10^{6}$ rotifers. Because Artemia metanauplii are highly pigmented, they were not given Carophyll, but only enrichment mix in the proportion of 2.5 or $5 \mathrm{~g}$ per $10^{6}$ metanauplii. Newly-hatched nauplii do not begin to 
feed before several hours, and so they were not esspecially enriched. However, considering that their hatching is not synchronal and that the oldest nauplii could feed, they were put into the enrichment medium simultaneously with either rotifers or the metanauplii.

In an attempt to have turbot treated through their live food against a possible infection, we used an antimicrobial agent, Tribrissen ${ }^{\circledR}$ (Wellcome's concentrate 48). This drug is composed of a suspension of $40 \mathrm{~g}$ sulphadiazine per $100 \mathrm{ml}$, linked with trimethoprim $(8 \mathrm{~g} / 100 \mathrm{ml})$. This suspension was put into an electric mixer with seawater and - if the live food organisms were also enriched - with the enrichment mix (and melted Carophyll for the rotifers).

In every case of enrichment and/or treatment, the procedure remained the same : after mixing, the suspension was screened through $48 \mu \mathrm{m}$ mesh in order to remove the particles too big to be filtered by the live food organisms which were given this suspension. These organisms were left in the bubbling suspension for $1 / 2$ hour, before pouring them within their medium into 10-1 containers above the larval rearing tanks. They were then offered to turbot through a dripping water supply.

The daily amount of Tribrissen for each treated lot was irrespective of its live food amount : the initial amount was $1 \mathrm{ml} / \mathrm{lot} /$ day from day 3 up to day $6,2 \mathrm{ml}$ from day 7 up to day 20 , and $1 \mathrm{ml}$ again from day 21 up to day 29 . The sulphadiazine amounts actually given to the live food organisms are unknown because of the withdrawal of the biggest particles. However, the concentration of Tribrissen was very low in the larval rearing tanks, since the suspension was introduced drop by drop, whereas the renewing water flow was increased from $20 \mathrm{l} / \mathrm{h}$ on day 3 up to $100 \mathrm{l} / \mathrm{h}$ on day 29. In vitro activity tests were made by Mc CarTHY, STEvenson \& SAlSBURY (1974) with trimethoprimlinked sulphadiazine on several strains of fishpathogenic bacteria : the minimum inhibitory coefficients were between 0.6 and $25 \mu \mathrm{g} / \mathrm{ml}$. More recently, Austin, Morgan \& Alderman (1981-1982) rejected Tribrissen from the list of the most effective agents against turbot-pathogenic bacteria and found that the sole trimethoprim-linked sulphonamide which they selected (sulphamethoxazole/trimethoprim) failed to reduce the numbers of viable bacterial cells of pathogenic bacteria, at the concentrations of $25-100 \mu \mathrm{g} / \mathrm{ml}$. Consequently, in our experiments, Tribrissen was not concentrated enough in the larval rearing tanks in order to act directly on turbot, but only by means of their live food.

\section{Weaning of turbot}

The turbot were transferred to clean tanks by day 30 ; they were weaned from day 31 up to day 34-35. During these 4 or 5 days, the addition of Artemia was delayed gradually from morning to evening, while compound diet was offered beforehand. The composition of this diet (tabl. 3) was derived from one used for weaning sole (GATEsoupe \& LuQuer, 1981-1982). Flesh of a clam, Callista chione, was put into an electric mixer with Carophyll melted in hot water and choline chloride. After obtaining a fluid mixture, it was poured into mixed powders and oil, which were then kneaded until a homogeneous paste was achieved. This paste was screened through a $630 \mu \mathrm{m}$ sieve, giving semi-moist crumbs which were stored at $4{ }^{\circ} \mathrm{C}$ and used for one week. 


\section{Results}

The survival curves are shown in figures 2,3 and 4 . All the lots which were not treated with Tribrissen presented a mortality peak by day 7-8. Only 5, 15 and 7 p. 100 of lots $1 \mathrm{~A}, 1 \mathrm{D}$ and $1 \mathrm{DE}$ respectively survived to day 10 , and so they were discontinued. On day 20 , the last 13 fish surviving in lot $2 \mathrm{D}$ were sampled for growth analysis. In contrast, the lots fed with live food organisms treated with Tribrissen did not present a mortality peak in their first days of feeding : on day 14, the survival rates obtained with treatment DT were between 21 and 33 p. 100, and those obtained with treatment DET between 36 and 69 p. 100.

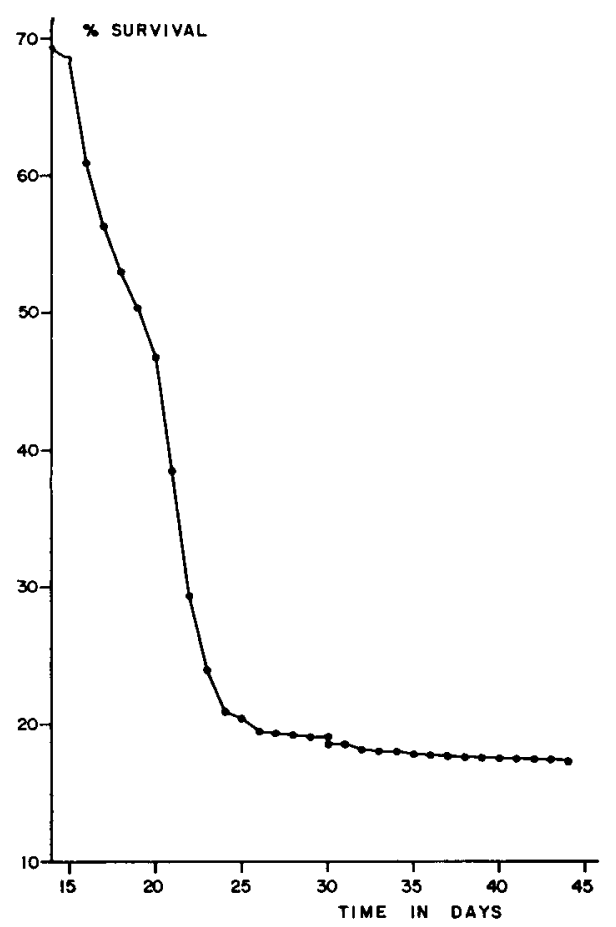

FIG. 2

Survival of turbot in experiment 1.

Courbe de survie du lot DET de l'expérience 1.

- : lot $1 \mathrm{DET}$ - lots $1 \mathrm{~A}, 1 \mathrm{D}$ and $1 \mathrm{DE}$ were not figured as their cultivation was discontinued on day 10 because of their low survival rates.

Courbe de survie du lot DET de l'expérience 1, ayant reçu des proies vivantes enrichies en substances nutritives et traitées au Tribrissen. Les autres lots, sans traitement anti-bactérien, ont été arrêtés au jour 10 en raison de leur survie trop faible. 


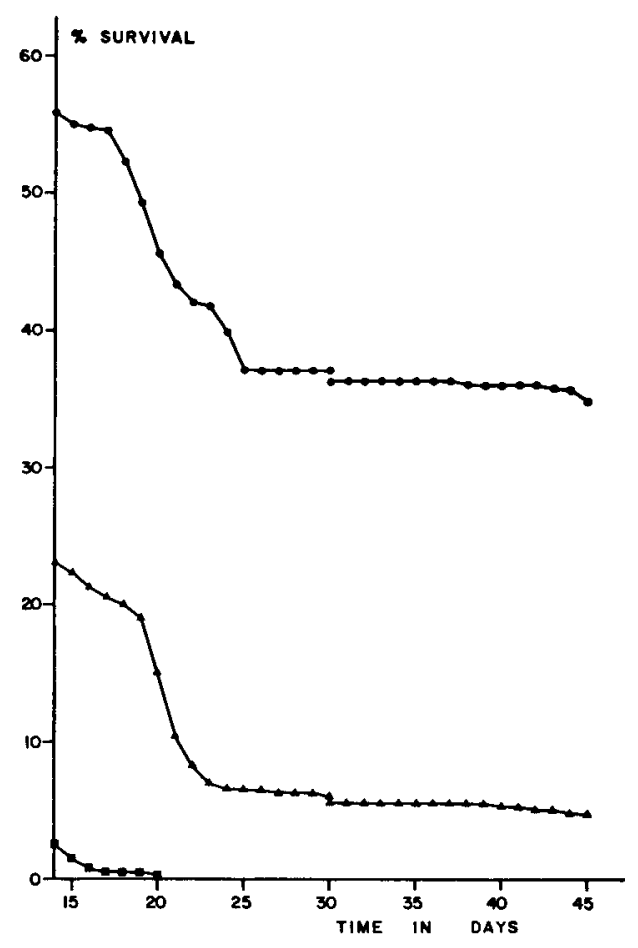

FIG. 3

Survival of turbot in experiment 2.

Courbes de survie des turbots dans l'expérience 2.

a : lot 2 D - A : lot 2 DT - $\bullet: \operatorname{lot} 2$ DET.

: lot $2 \mathrm{D}$ sans traitement au Tribrissen ni enrichissement - $\Delta$ : lot $2 D T$ traité au Tribrissen sans enrichissement - $\bullet$ : lot 2 DET traité et enrichi.

A second mortality peak of variable importance was observed about day 20 , without apparent relation with treatments DT and DET : the survival rates on day 30 were between 6 and 27 p. 100 with treatment DT, and between 19 and 38 p. 100 with treatment DET (tabl. 4). This second mortality peak was particularly high for lot $1 \mathrm{DET}$, many larvae of which remained close to the surface with an hypertrophy of their swim-bladder, and then died. This phenomenon - likely due to gas supersaturation of the water - was not observed in experiments 2 and 3.

The hemispheric base of 2501 tanks was found especially suitable for weaning turbot : most fish were already benthic and the shape of this base caused their wastes to gather into the central drain. Actually, survival rates from day 30 up to day 45 were between 53 and 96 p. 100 (tabl. IV), without significant difference between the weaning survival of treatment DT and DET. 


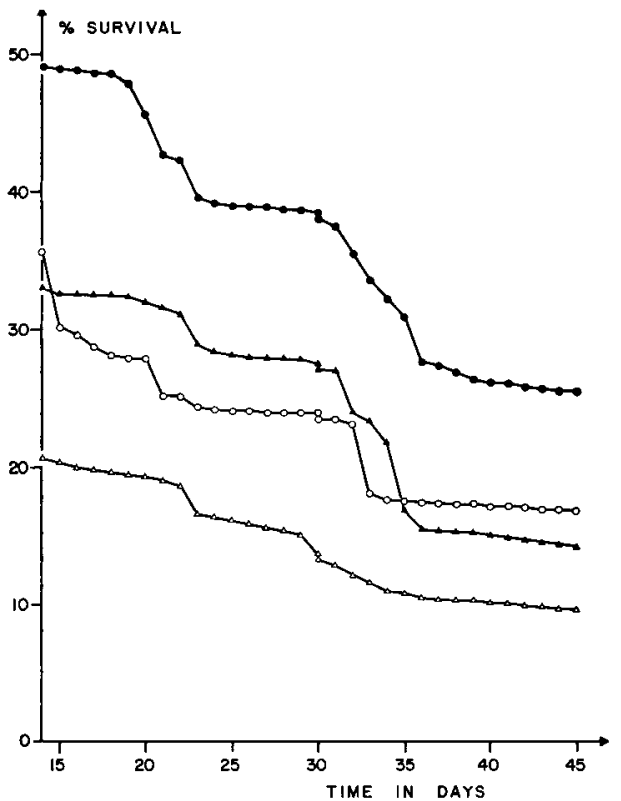

FIG. 4

Survival of turbot in experiment 3.

Courbes de survie des turbots dans l'expérience 3.

$\Delta: \operatorname{lot} 3$ DT 1 - $\triangle: \operatorname{lot} 3$ DT $2-\bullet: \operatorname{lot} 3$ DET 1 - O : lot 3 DET 2.

$\Delta:$ lot $3 D T 1 ; \triangle$ : lot $3 D T 2$, traités au Tribrissen sans enrichissement - $\bullet$ : lot 3 DET 1; $O$ : lot 3 DET 2, traités au Tribrissen et enrichis.

TABLE 4

Survival of turbot by day 30 and 45 .

Taux de survie des turbots à la fin de la période d'alimentation sur proies vivantes (jour 30) et à la fin des expériences (jour 45).

\begin{tabular}{|c|c|c|c|c|c|}
\hline \multirow{2}{*}{ Lot } & \multirow{2}{*}{ Day } & \multicolumn{2}{|c|}{ Survivors } & \multirow{2}{*}{$\begin{array}{l}\text { Number of fish put } \\
\text { into weaning tanks }\end{array}$} & \multirow{2}{*}{$\begin{array}{l}\text { Weaning survival } \\
\text { (p. 100) }\end{array}$} \\
\hline & & Number & p. 100 & & \\
\hline $1 \mathrm{DET}$ & $\begin{array}{l}30 \\
45\end{array}$ & $\begin{array}{l}946 \\
858 \\
\end{array}$ & $\begin{array}{l}19 \\
17 \\
\end{array}$ & $\begin{array}{l}926 \\
-\end{array}$ & $\overline{93}$ \\
\hline $2 \mathrm{DT} \ldots \ldots$ & $\begin{array}{l}30 \\
45\end{array}$ & $\begin{array}{l}258 \\
199\end{array}$ & $\begin{array}{l}6 \\
5\end{array}$ & $\begin{array}{l}235 \\
-\end{array}$ & $\overline{85}$ \\
\hline 2 DET & $\begin{array}{l}30 \\
45 \\
\end{array}$ & $\begin{array}{l}1546 \\
1462 \\
\end{array}$ & $\begin{array}{l}37 \\
35 \\
\end{array}$ & $1526^{a}$ & $\overline{96}$ \\
\hline 3 DT $1 \ldots$ & $\begin{array}{l}30 \\
45\end{array}$ & $\begin{array}{r}1370 \\
715\end{array}$ & $\begin{array}{l}27 \\
14\end{array}$ & 1350 & $\overline{53}$ \\
\hline $3 \mathrm{DT} 2$ & $\begin{array}{l}30 \\
45\end{array}$ & $\begin{array}{l}684 \\
485\end{array}$ & $\begin{array}{l}14 \\
10\end{array}$ & $\frac{664}{-}$ & $\overline{73}$ \\
\hline 3 DET 1 & $\begin{array}{l}30 \\
45\end{array}$ & $\begin{array}{l}1921 \\
1274\end{array}$ & $\begin{array}{l}38 \\
25\end{array}$ & 1901 & $\overline{67}$ \\
\hline 3 DET 2 & $\begin{array}{l}30 \\
45\end{array}$ & $\begin{array}{r}1197 \\
859 \\
\end{array}$ & $\begin{array}{l}24 \\
17 \\
\end{array}$ & $\begin{array}{c}1177 \\
-\end{array}$ & $\overline{71}$ \\
\hline
\end{tabular}

(a) Dispatched into 2 lots of 763 fish each. 
As far as the mean weight (tabl. 5) and length (tabl. 6) are concerned, no clear difference appeared between treatments DT and DET up to day 30 . However, the mean weight was between 130 and $170 \mathrm{mg}$ on day 45 with treatment DT, while it was between 225 and $630 \mathrm{mg}$ with treatment DET.

TABLE 5

Mean weight (mg) of turbot and statistical significance

( $a, b$ and $c$ indicate into which partition the means are broken up within each experiment).

Poids moyen ( $\mathrm{mg}$ ) des larves de turbot.

Les lettres $a, b$ et $c$, indiquent la partition des moyennes à l'intérieur d'une même expérience.

\begin{tabular}{|c|c|c|c|c|c|}
\hline Day & 10 & 15 & 20 & 30 & 45 \\
\hline \multicolumn{6}{|l|}{ Experiment 1} \\
\hline $1 \mathrm{~A} \ldots \ldots \ldots \ldots$ & $0.55^{b}$ & - & - & - & - \\
\hline $1 \mathrm{D} \ldots \ldots \ldots \ldots$ & $0.41^{\circ}$ & - & - & - & - \\
\hline $1 \mathrm{DE}$ & $0.62^{\mathrm{nb}}$ & - & - & - & - \\
\hline $1 \mathrm{DET}$ & $0.75^{\mathrm{a}}$ & 2.96 & 3.85 & 43.4 & 570 \\
\hline Statistical significance & $* * *$ & - & 一 & - & - \\
\hline \multicolumn{6}{|l|}{ Experiment 2} \\
\hline $2 \mathrm{D}$ & $0.46^{\mathrm{c}}$ & $1.08 \mathrm{c}$ & $5.44 \mathrm{ab}$ & - & - \\
\hline $2 \mathrm{DT}$ & $0.70^{\mathrm{b}}$ & $2.77^{\mathrm{b}}$ & $3.41^{\mathrm{b}}$ & $47.8^{b}$ & $170^{b}$ \\
\hline 2 DET & $0.97^{a}$ & $4.01^{\mathrm{a}}$ & $7.49 \mathfrak{a}$ & $105.8^{\mathrm{a}}$ & $\begin{array}{l}620^{\mathrm{a}} \\
630^{\mathrm{a}}\end{array}$ \\
\hline Statistical significance & $* * *$ & $* * *$ & $* * *$ & $* * *$ & $* * *$ \\
\hline \multicolumn{6}{|l|}{ Experiment 3} \\
\hline 3 DT $1 \ldots$ & $1.19 \mathrm{ab}$ & $3.69 \mathrm{ab}$ & $18.1^{\mathrm{a}}$ & $84.4^{\mathrm{a}}$ & $140^{\mathrm{b}}$ \\
\hline 3 DT $2 \ldots \ldots$ & $0.82^{b}$ & $2.50^{\mathrm{bc}}$ & $16.3^{\mathrm{ab}}$ & $56.8^{\mathrm{b}}$ & $129 \mathrm{~b}$ \\
\hline 3 DET $1 \ldots \ldots \ldots$ & $1.37^{a}$ & $4.44 \mathbf{a}$ & $19.4^{\mathrm{a}}$ & $98.1^{\mathrm{a}}$ & $247^{a}$ \\
\hline 3 DET $2 \ldots \ldots \ldots$ & $1.14^{a b}$ & $2.04 e$ & $11.5^{\mathrm{b}}$ & $72.9^{a b}$ & $225^{a}$ \\
\hline Statistical significance & $* *$ & $* * *$ & $* *$ & $* *$ & $* * *$ \\
\hline
\end{tabular}


TABLE 6

Mean length $(\mathrm{mm})$ of turbot and statistical significance

( $a, b$ and $c$ indicate into which partition the means are broken up within each experiment).

Longueur moyenne ( $\mathrm{mm}$ ) des larves de turbot.

Les lettres $a$, $b$ et $c$, indiquent la partition des moyennes à l'intérieur d'une même expérience.

\begin{tabular}{|c|c|c|c|c|c|}
\hline Day & 10 & 15 & 20 & 30 & 45 \\
\hline \multicolumn{6}{|l|}{ Experiment 1} \\
\hline $1 \mathrm{~A} \ldots \ldots$ & $4.0^{\mathrm{b}}$ & - & - & - & - \\
\hline $1 \mathrm{D} \ldots \ldots \ldots \ldots$ & $3.8^{\mathrm{b}}$ & - & - & - & - \\
\hline $1 \mathrm{DE} \ldots \ldots \ldots \ldots$ & $4.1^{b}$ & - & - & - & - \\
\hline $1 \mathrm{DET} \quad \ldots \ldots \ldots$ & $4.5^{\mathrm{a}}$ & 6.2 & 7.7 & 15.6 & - \\
\hline Statistical significance & $* * *$ & - & - & 一 & - \\
\hline \multicolumn{6}{|l|}{ Experiment 2} \\
\hline $2 \mathrm{D} \ldots \ldots \ldots \ldots$ & $4.1^{b}$ & $4.8^{\mathrm{e}}$ & $6.7 \mathrm{ab}$ & - & - \\
\hline 2 DT $\ldots \ldots \ldots$ & $4.3^{\mathrm{ab}}$ & $5.9 \mathrm{~b}$ & $7.3^{b}$ & $16.0^{\mathrm{b}}$ & 一 \\
\hline 2 DET $\ldots \ldots \ldots$ & $4.6^{\mathrm{a}}$ & 6.9 .1 & $8.7^{\mathrm{a}}$ & $20.9^{a}$ & - \\
\hline Statistical significance & $*$ & $* * *$ & $* * *$ & $* * *$ & \\
\hline \multicolumn{6}{|l|}{ Experiment 3} \\
\hline 3 DT $1 \ldots$ & $4.5^{\mathrm{ab}}$ & $6.2^{\mathrm{b}}$ & $10.2^{\mathrm{a}}$ & $18.7^{\mathrm{ab}}$ & $22.1^{\mathrm{b}}$ \\
\hline 3 DT $2 \ldots \ldots \ldots$ & $4.2^{\mathrm{b}}$ & $5.3^{\text {he }}$ & $9.6^{\mathrm{ab}}$ & $16.4^{b}$ & $21.3 \mathrm{~b}$ \\
\hline 3 DET $1 \ldots \ldots \ldots$ & $4.7^{\mathrm{a}}$ & $7.0^{\mathrm{a}}$ & $10.6^{4}$ & $19.1^{\mathrm{a}}$ & $26.0^{\mathrm{a}}$ \\
\hline 3 DET $2 \ldots \ldots \ldots$ & $4.5^{\mathrm{ab}}$ & $5.5^{\mathrm{c}}$ & $8.5^{\mathrm{b}}$ & $17.5^{\mathrm{ab}}$ & $24.8^{\mathrm{a}}$ \\
\hline Statistical significance & $*$ & $* * *$ & $* *$ & * & $* * *$ \\
\hline
\end{tabular}

\section{Discussion}

Clearly, Tribrissen treatment of the rotifers appeared to be required for keeping a significant rate of turbot survival during the first step of the food sequence. We cannot know exactly how this drug acted. A pathological infection was probably encountered, either in the rotifers, or in their medium, or directly in turbot. After these experiments were carried out, Nicolas (1982) investigated the intestinal microflora of turbot larvae. In a preliminary study, this author found that bacteria from live food organisms had little if any effect upon turbot microflora, which comprised mainly Aeromonas hydrophila — a potentially pathogenic species. If an infection originated from turbot microflora in our experiments, the high dilution rate of Tribrissen in the larval rearing tanks could not allow its action in the bath, whereas the drug might have been effective after ingestion within the rotifers. Furthermore, the value of treating Artemia could not be examined in these preliminary experiments.

The effect of enriching the rotifers was less clear. Indeed, if in the first steps the survival rate of turbot was superior when they were fed with enriched rotifers, 


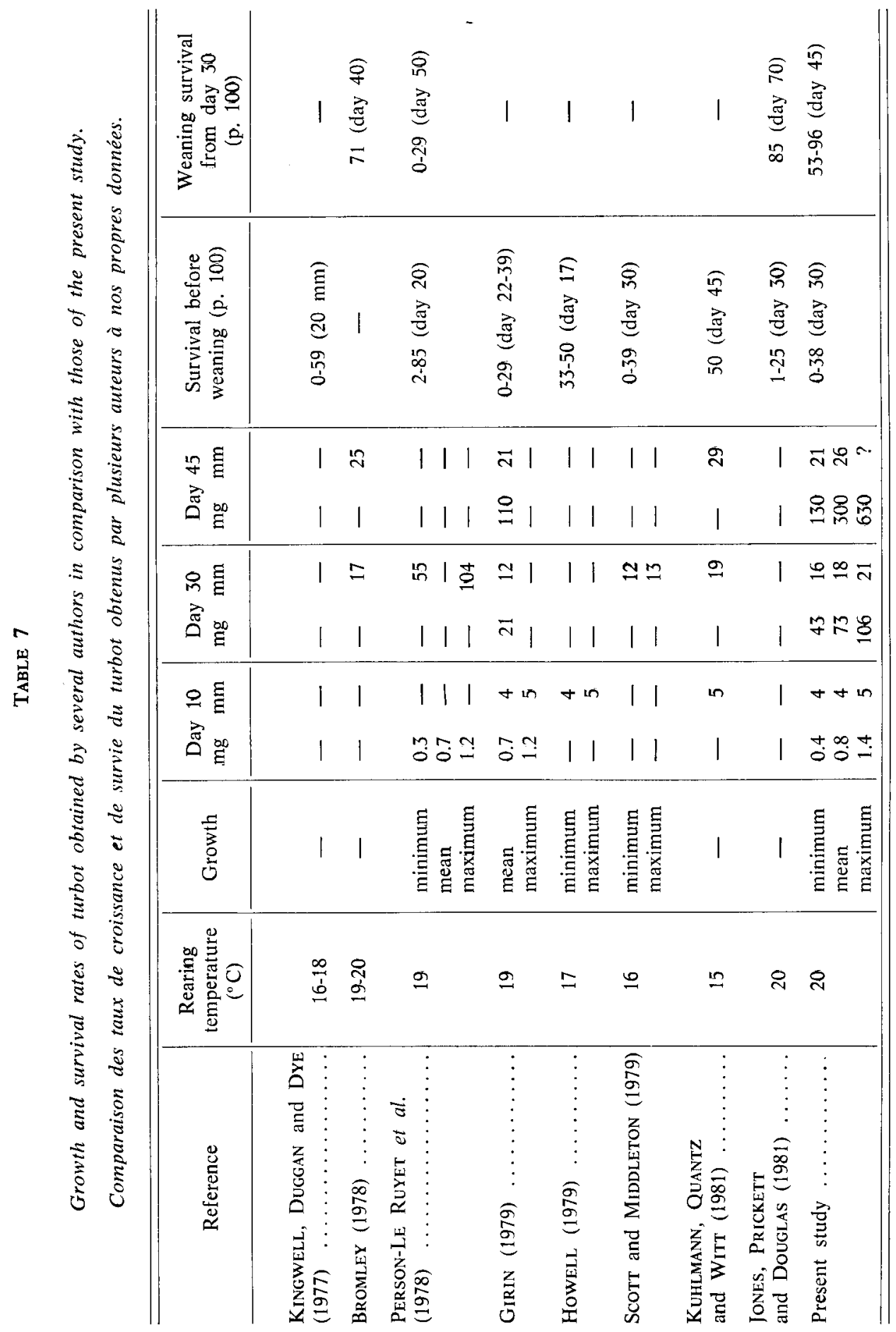


their growth rate was not systematically higher up to day 30. A nutritional disease generally tends to reduce growth rate first and then survival. For instance, when Howell (1979) or Scott and MidDleton (1979) tested the dietary value for turbot of rotifers fed with two species of algae, they observed a difference both in growth and survival rates. A possible interpretation of this phenomenon would be an effect of synergy between Tribrissen and the enrichement mix, which might enable, better than the drug alone, turbot to withstand a pathological infection.

The presented results, compared to those obtained from other authors (tabl. 7), appear good, though not exceptional. However, between 67 and 96 p. 100 of turbot which had been fed with enriched live food organisms, survived from day 30 up to day 45 , with a final weight between 225 and $630 \mathrm{mg}$. These survival and growth performances were excellent : for instance, PERSON-LE RUYET et al. (1978) obtained between 315 and $370 \mathrm{mg}$ as mean weight by day 40, while live food only was supplied. These authors obtained also up to $1620 \mathrm{mg}$ as mean weight by day 50 , after weaning from day 30 , but with a poor survival rate $(8 \%$ from day 30 up to day 50). Bromley (1978) obtained a result more similar to ours : after weaning by day 30 , he obtained 71 p. 100 survivors from this date up to day 40 , with $25 \mathrm{~mm}$ as mean length by day 45 .

Finally, the growth rate of turbot was improved by the enrichment of their live food organisms, but this effect was delayed after weaning. In their above-mentioned study Howell, Bromley \& AdKINS (1981) concluded : «Inconsistent weaning success has been a feature of turbot larvae rearing and at least a part of this variability may be accounted for by inadequate feeding beforehand. Dietary deprivation is likely to lead to reduced appetite and hence a greater reluctance to accept a novel feed . However, their results were different from ours, since the growth and survival rates that they obtained were already depressed before the weaning stage, when Artemia were deficient. This deficiency increased the weaning mortality, but the post-weaning growth rates were not reported.

\section{Conclusion}

This preliminary study has shown the possibility of combating a pathological infection of turbot by treating the rotifers on which they were fed. Moreover, the importance of the dietary value of the live food organisms appeared particularly important under stress conditions, whether this stress was occasional like an infection, or ineluctable like the weaning stage. Obviously, further investigations are required in order to analyse it step by step.

Accepted for publication in October 1982.

\section{Acknowledgements}

This study was supported by the C.N.E.X.O. (Contract $\mathrm{n}^{\circ}$ 79-6056), and performed at the «Centre Océanologique de Bretagne», Brest, France. The figures were prepared by Mrs S. Gros. The author would also like to thank Drs. J. Guillaume and P. LuQueT for their helpful suggestions during the preparation of the manuscript. 


\section{Résumé}

Influence de traitements alimentaire et anti-bactérien de proies vivantes sur les taux de survie et de croissance de larves de Turbot (Scophthalmus maximus) ainsi que sur leur accoutumance à un aliment inerte

Le traitement des proies vivantes destinées aux larves de turbot a consisté à leur faire ingérer des substances nutritives et/ou antibactériennes juste avant distribution (tabl. 1 à 3 et figure 1). L'absence de traitement anti-infectieux a conduit à des taux de survie três faibles, alors que ce taux variait entre 21 et 33 p. 100 quatorze jours après l'éclosion lorsque le seul traitement avait été appliqué au rotifère Brachionus plicatilis; lorsque les rotifères avaient été enrichis en substances nutritives, le taux de survie des larves de turbot variait au jour 14 de 36 à 69 p. 100 (figures 2 à 4). Il est probable qu'un agent pathogène se soit attaqué aux larves de turbot dans cette première période de leur élevage tandis que la qualité alimentaire des rotifères semble également importante pour l'obtention de bons taux de survie. Les mêmes traitements furent ensuite appliqués à Artemia salina. L'accoutumance à un aliment inerte ayant débuté au jour 30 , les turbots nourris de proies vivantes enrichies en substances nutritives présentaient au jour 45 un taux de survie compris entre 17 et 35 p. 100 pour un poids moyen de 225 à $630 \mathrm{mg}$. Lorsque les proies vivantes n'avaient pas été enrichies, le taux de survie n'était que de 5 à 14 p. 100 au jour 45 , pour un poids moyen compris entre 130 et $170 \mathrm{mg}$ (tabl. 4 à 6). Si ces expériences préliminaires ne permettent pas de déterminer l'utilité du traitement antibactérien d'Artemia salina, il semble par contre que bien qu'une différence systématique entre les taux de croissance n'ait pu être observée pendant la phase d'alimentation avec des proies vivantes, l'enrichissement de ces proies avec des substances nutritives se soit révélé utile pour permettre aux turbots de conserver un bon taux de croissance lors de la période d'accoutumance à un aliment inerte.

\section{References}

Austin B., Morgan D.A., Alderman D.J., 1981/1982. Comparison of antimicrobial agents for control of vibriosis in marine fish. Aquaculture, 26, 1-12.

Bromley P.J., 1978. The weaning of hatchery-reared Turbot larvae (Scophthalmus maximus L.) on a dry diet. Aquaculture, 13, 339-345.

Bucke D., 1980. A preliminary histological study of normal and pathological tissues in cultivated turbot (Scophthalmus maximus L.). Proc. of I.C.E.S. special meet. on diseases of commercially important marine fish and shell-fish, $\mathrm{n}^{\circ} 5,7 \mathrm{p}$.

Fontaine C.T., Revera D.B., 1980. The mass culture of the rotifer, Brachionus plicatilis, for use as foodstuff in aquaculture. Proc. World Maricult. Soc., 11, 211-218.

Gatesoupe F.J., LuQuet P., 1981. Practical diet for mass culture of the rotifer Brachionus plicatilis : application on larval rearing of Sea-bass, Dicentrarchus labrax. Aquaculture, 22, 149-163.

Gatesoupe F.J., LuQuet P., 1981/1982. Weaning of the sole (Solea solea) before metamorphosis. Aquaculture, 26, 359-368.

Gatesoupe F.J., RoBin J.H., 1981. Commercial single-cell proteins either as sole food source or in formulated diets for intensive and continuous production of rotifers (Brachionus plicatilis). Aquaculture, 25, 1-15.

Gatesoupe F.J., RoBin J.H., 1982. The dietary value for sea-bass larvae (Dicentrarchus labrax) of the rotifer Brachionus plicatilis fed with or without a laboratory-cultured alga. Aquaculture, 27, 121-127.

GIRIN M., 1979. Méthodes de production des juvéniles chez trois poissons marins, le bar, la sole et le turbot. Rapports scientifiques et techniques, Publ. 39, C.N.E.X.O. (France), 202 p. 
Howell B.R., 1979. Experiments on the rearing of larval turbot, Scophthalmus maximus L. Aquaculture, 18, $215-225$.

Howell B.R., Bromley P.J., Adkins T.C., 1981. The food value of Artemia for larval turbot, Scophthalmus maximus; effects on survival, growth and acceptance of a compound feed. Proc. of I.C.E.S. Maricult. Committee, F, 10, 4 p.

Jones A., Prickett R.A., Douglas M.T., 1981. Recent developments in techniques for rearing marine flatfish larvae, particularly Turbot, Scophthalmus maximus L., on a pilot commercial scale. In R. Lasker and K. Sherman (eds), Early life History of Fish II, Proc. of I.C.E.S. Symp., Woods Hole (U.S.A.), April 2-5, 1979. Rapp. P.V. Réun. Cons. Int. Explor. Mer, 178, 522-526

Kingwell S.J., Duggan M.C., Dye J.E., 1977. Large scale handling of the larvae of the marine flatfish turbot, Scophthalmus maximus L., and Dover Sole, Solea solea L., with a view to a subsequent fattening under farming conditions. 3rd Work. Group Maricult. I.C.E.S., Brest, France, May 10-13, 1977. Publ. C.N.E.X.O., Actes colloq., 4, 27-34.

Kuhlmann D., Quantz G., WITT U., 1981. Rearing of turbot larvae (Scophthalmus maximus L.) on cultured food organisms and post-metamorphosis growth on natural and artificial food. Aquaculture, 23, 183-196.

Mc Carthy D.H., Stevenson J.P., Salsbury A.W., 1974. Combined in vitro activity of trimethoprim and sulphonamides on fish-pathogenic bacteria. Aquaculture, 3, 87-91.

Nicolas J.L., 1982. La microflore bactérienne des larves de turbot (Scophthalmus maximus) et de leur environnement dans les élevages : premières analyses. Poster présenté au Colloque Int. de Bactériologie marine (C.N.R.S.), Marseille, 17-19 mai 1982.

Person-Le Ruyet J., Alexandre J.C., Le Roux A., Nedelec G., 1978. La génération 1977 de turbot (Scophthalmus maximus L.) au Centre Océanologique de Bretagne, C.N.E.X.O., France. Proc. I.C.E.S. Maricult. Committee, G, 55, 29 p.

Scott A.P., Middeteron C., 1979. Unicellular algae as a food for turbot (Scophthalmus maximus L.) larvae. The importance of dietary long-chain polyunsaturated fatty acids. Aquaculture, 18, 227-240.

SoKal R.R., RohlF F.J., 1969. Biometry. W.H. Freeman and Co, San Francisco, CA, 395-397. 